\title{
Synergistic integration of metallic Bi and defects on BiOI: Enhanced photocatalytic NO removal and conversion pathway
}

\author{
Minglu Sun a, Wendong Zhang b, Yanjuan Sun a,\#, Yuxin Zhang c, Fan Dong a,d,* \\ a Chongqing Key Laboratory of Catalysis and New Environmental Materials, College of Environment and Resources, Chongqing Technology and Business \\ University, Chongqing 400067, China \\ b Chongqing Key Laboratory of Inorganic Functional Materials, Department of Scientific Research Management, Chongqing Normal University, Chongqing \\ 401331, China \\ c College of Materials Science and Engineering, Chongqing University, Chongqing 400044, China \\ ${ }^{\mathrm{d}}$ Research Center for Environmental Science \& Technology, Institute of Fundamental and Frontier Sciences, University of Electronic Science and \\ Technology of China, Chengdu 611731, China.
}

\section{A R T I C L E I N F O}

\section{Article history:}

Received 26 August 2018

Accepted 17 October 2018

Published 5 June 2019

\section{Keywords:}

Surface plasmon resonance

Bi metal

BiOI

Photocatalysis

Oxygen vacancy

Reaction mechanism

\begin{abstract}
A B S T R A C T
Surface plasmon resonance (SPR) of metals may provide a way to improve light absorption and utilization of semiconductors, achieving better solar light conversion and photocatalysis efficiency. This study uses the advantages of SPR in metallic Bi and artificial defects to cooperatively enhance the photocatalytic performance of BiOI. The catalysts were prepared by partial reduction of $\mathrm{BiOI}$ to form Bi@defective BiOI, which showed highly enhanced visible photocatalytic activity for $\mathrm{NO}_{x}$ removal. The effects of reductant quantity on the photocatalytic performance of Bi@defective BiOI were investigated. The as-prepared photocatalyst (Bi/BiOI-2) using 2 mmol of reductant $\mathrm{NaBH}_{4}$ showed the most efficient visible light photocatalytic activity. This enhanced activity can be ascribed to the synergistic effects of metallic Bi and oxygen vacancies. The electrons from the valence band tend to accumulate at vacancy states; therefore, the increased charge density would cause the adsorbed oxygen to transform more easily into superoxide radicals and, further, into hydroxyl radicals. These radicals are the main active species that oxidize NO into final products. The SPR effect of elemental $\mathrm{Bi}$ enables the improvement of visible light absorption efficiency and the promotion of charge carrier separation, which are crucial factors in boosting photocatalysis. NO adsorption and reaction processes on $\mathrm{Bi} / \mathrm{BiOI}-2$ were dynamically monitored by in situ infrared spectroscopy (FT-IR). The Bi/BiOI photocatalysis mechanism co-mediated by elemental Bi and oxygen vacancies was proposed based on the analysis of intermediate products and DFT calculations. This present work could provide new insights into the design of high-performance photocatalysts and understanding of the photocatalysis reaction mechanism for air-purification applications.
\end{abstract}

(C) 2019, Dalian Institute of Chemical Physics, Chinese Academy of Sciences. Published by Elsevier B.V. All rights reserved.

\footnotetext{
* Corresponding author. Tel: +86-15922570175; E-mail: dfctbu@126.com

\# Corresponding author. E-mail: syhsyj@163.com

This work was supported by the National Natural Science Foundation of China (21501016, 21777011 and 21822601), the National Key R\&D Program of China (2016YFC02047), the Innovative Research Team of Chongqing (CXTDG201602014), the Key Natural Science Foundation of Chongqing (cstc2017jcyjBX0052), and the National Ten Thousand Talent Program of China.

DOI: 10.1016/S1872-2067(18)63195-X | http://www.sciencedirect.com/science/journal/18722067 | Chin. J. Catal., Vol. 40, No. 6, June 2019
} 


\section{Introduction}

With increasing attention on serious air pollution problems, efficient reduction of nitrogen oxides in air has long been a hot topic in the field of photocatalysis [1]. Among various potential technologies, heterogeneous photocatalysis using semiconductor materials, such as bismuth-based layered semiconductors, has displayed promising results for environmental governance and solar energy conversion [2-12]. BiOI, which has a layered structure consisting of $\left[\mathrm{Bi}_{2} \mathrm{O}_{2}\right]^{2+}$ layers sandwiched between two sheets of I ions, is a visible-light photocatalyst that can be activated by irradiation with visible light due to the narrow band gap $[13,14]$. However, serious recombination of photogenerated charges prohibits the photocatalytic performance of BiOI.

Since visible light comprises the major part of solar light, a number of approaches have been developed to boost the visible light activity of photocatalysts, involving doping, metal loading, and compositing [15-25]. In particular, many studies have been conducted to prove that defects, especially oxygen vacancies, are the most reactive sites on the catalyst surface [26]. In addition, the photo-response range can be expanded by the generation of oxygen vacancies that could narrow the band gap by formation of oxygen-vacancy states located within the band gap. Moreover, oxygen defects could also serve as photoinduced charge traps to prevent electron-hole recombination and adsorption sites where the charges were transferred to adsorbed species [27]. Thus, the introduction of oxygen defects in oxide semiconductors should be conducive to improvement in visible photocatalytic activity.

To further enhance the visible light photocatalytic activity of BiOI, various modification methods such as metal deposition or doping [28-31] are applied. Integration of nanoscale plasmonic metals into photocatalysts has been utilized as an effective approach to construct visible-light-induced plasmonic composite photocatalysts [32]. Compared with noble metals such as Au or Ag, non-noble metals such as bismuth (Bi) have significant advantages of high efficiency, low cost, easy availability, and facile synthesis. UV and visible-light active semi-metal Bi with surface plasmon resonance (SPR) from the collective oscillation of its surface electrons $[33,34]$ enables hot carriers to transfer from the plasmonic metal to BiOI, thus enhancing the charge carrier separation of semiconductor composites [22,35,36].

Recently, Dong et al. [37] found that the SPR effect and oxygen defect of the semiconductor photocatalysts can significantly improve the photocatalytic performance. However, the synergistic effect of SPR and the multiple intermediate levels of energy excited by oxygen defects have not been revealed, which inspired the construction of heterojunctions with SPR and oxygen defects, simultaneously, to achieve dramatically enhanced photocatalytic performance. BiOI is a typical semiconductor photocatalyst, while pristine BiOI undergoes limited visible light photocatalytic activity. In addition, it is appealing to explore the mechanism of the synergistic integration of elemental $\mathrm{Bi}$ and defects for promoting the photocatalysis efficiency of BiOI.

In the present study, metallic Bi was deposited in situ on Bi-
OI nanosheets by the reduction of partial $\mathrm{Bi}^{3+}$ on the surface of BiOI along with the creation of oxygen defects. Further experimental and theoretical investigations confirmed that the obtained catalysts consisted of BiOI phase, elemental Bi phase, and oxygen defects. The synergy effect of metallic Bi and oxygen defects could cause BiOI to be highly active under visible irradiation for NO removal. The detailed mechanisms for the synergistic integration of metallic $\mathrm{Bi}$ and defects on $\mathrm{BiOI}$ under visible light irradiation were proposed based on in situ DRIFTS, EPR, and DFT calculations. The conversion pathway of photocatalytic NO oxidation was also revealed. The present work could provide a new strategy for the development of high-performance photocatalysts and the understanding of the gas-phase reaction mechanisms for environmental and energetic applications.

\section{Experimental}

\subsection{Sample preparation}

The chemical reagents used in this experiment were analytical grade. The preparation process is as follows: $4 \mathrm{mmol}$ (1.949 g) of bismuth nitrate $\left(\mathrm{Bi}\left(\mathrm{NO}_{3}\right)_{3} \cdot 5 \mathrm{H}_{2} \mathrm{O}\right)$ and $25 \mathrm{~mL}$ of distilled water were added in a $50-\mathrm{mL}$ beaker and kept stirring for $30 \mathrm{~min}$ to dissolve. Then, $4 \mathrm{mmol}(0.664 \mathrm{~g})$ of KI was dissolved in distilled water $(10 \mathrm{~mL})$ and added to bismuth nitrate solution and kept stirring for $30 \mathrm{~min}$. The mixture was aged in the water bath under $80^{\circ} \mathrm{C}$ for $2 \mathrm{~h}$. After the precipitate was cooled to room temperature, it was washed (twice with water and twice with ethanol and dried at $55^{\circ} \mathrm{C}$ to obtain BiOI. Then, the prepared BiOI sample ( $2 \mathrm{mmol}$ ) was added into $20-\mathrm{mL}$ distilled water and kept stirring for $20 \mathrm{~min}$. At the same time, the $\mathrm{NaBH}_{4}$ solution was prepared by adding $\mathrm{NaBH}_{4}$ solid $(0.038,0.076$, 0.113 , and $0.189 \mathrm{~g}$ ) into $40-\mathrm{mL}$ distilled water. The $\mathrm{NaBH}_{4}$ solution was dropped into the BiOI suspension and kept stirring for $20 \mathrm{~min}$. The obtained sample was washed twice with water and twice with ethanol to obtain the final products, labeled Bi/BiOI-1, Bi/BiOI-2, Bi/BiOI-3, and Bi/BiOI-5.

\subsection{Characterization}

The crystal structure of the samples was analyzed by X-ray diffraction with $\mathrm{Cu} K_{\alpha}$ (XRD, Model D/Max RA, Rigaku Co., Japan). An X-ray photoelectron spectrometer (XPS, Thermo ESCALAB 250, USA) analyzed the chemical composition of the samples. A scanning electron microscope (SEM, JEOL Model JSM-6490, Japan) characterized the morphology of the samples. A $\mathrm{N}_{2}$ adsorption-desorption instrument (ASAP 2020, USA) measured the specific surface area (BET) and pore structure of the samples. UV-vis DRS (UV2550, Shimadzu) and photoluminescence spectra (PL, F-7000, Hitachi, Japan) were utilized to analyze the optical properties of the samples. The electron paramagnetic resonance (EPR) measurements of the samples were performed at $-196^{\circ} \mathrm{C}$ (FLsp920, England). Electron spin resonance (ESR) spectra of radicals that were spin-trapped using 5,5-dimethyl-1-pyrroline-n-oxide (DMPO) was employed to verify the formation of superoxide $\left(\bullet_{2}{ }^{-}\right)$and hydroxyl radi- 
cals $(\bullet \mathrm{OH})$.

\subsection{Evaluation of visible light activity}

The photocatalytic activity was evaluated by monitoring the NO concentration in a continuous stream reactor at room temperature. From the prepared sample, $0.1 \mathrm{~g}$ was ultrasonically dispersed in a $12-\mathrm{mm}$ diameter glass disk and dried at $60{ }^{\circ} \mathrm{C}$. After natural cooling, the mixture was placed in a rectangular reactor with a capacity of $4.5 \mathrm{~L}(30 \mathrm{~cm} \times 15 \mathrm{~cm} \times 10 \mathrm{~cm})$, covered with a layer of quartz glass, and a $150-\mathrm{W}$ commercial halogen tungsten lamp placed $20 \mathrm{~cm}$ above the reactor. For visible light catalytic activity tests, filters were used to remove light with wavelengths less than $420 \mathrm{~nm}$ from the beam. A low concentration of NO was prepared using standard air and NO standard gases with an original concentration of $100 \mathrm{ppm}$. The air flow rate was $2.4 \mathrm{~L} / \mathrm{min}$ and the NO gas flow rate was 15 $\mathrm{mL} / \mathrm{min}$. The air flow and the NO gas stream were mixed by means of a three-way valve to obtain an initial concentration of $600 \mathrm{ppb}$ of NO. The diluted NO was passed into the reactor, the NO concentration was stabilized, and the lamp was turned on. The $\mathrm{NO}_{x}$ analyzer (Thermo Scientific, 42i-TL, USA) was sampled every 1 min and the concentrations of $\mathrm{NO}, \mathrm{NO}_{2}$, and $\mathrm{NO}_{x}(\mathrm{NO}+$ $\mathrm{NO}_{2}$ ) were recorded. The removal ratio $(\eta)$ of NO can be calculated as $\eta=\left(1-C / C_{0}\right) \times 100 \%$, in which $C$ represents the NO concentration at the outlet of the reactor after turning on the lamp and $C_{0}$ represents the NO concentration when the adsorption-desorption equilibrium is reached before turning on the lamp.

\subsection{DFT calculations}

Spin-polarized DFT-D2 [38] calculations were carried out utilizing the "Vienna ab initio simulation package" (code VASP5.4) [39,40], using a universal gradient correlation function [41]. A plane-wave basis set with energy cut off at $400 \mathrm{eV}$ within the framework of the projector-augmented wave method was adopted. The Gaussian smearing width was set to $0.2 \mathrm{eV}$ $[42,43]$. The Brillouin zone was sampled at $3 \times 3 \times 1 \mathrm{~K}$ points. All atoms were allowed to converge to $0.01 \mathrm{eV} \AA^{-1}$. A $12 \times 8 \times 18$ supercell of BiOI, including 24 oxygen atoms, 18 bismuth atoms, and $12 \mathrm{I}$ atoms was employed. Then, $10 \mathrm{Bi}$ atoms were supported on the surface of BiOI $[44,45]$.

\subsection{In situ DRIFTS investigation on photocatalytic NO oxidation}

In situ infrared test equipment was composed of a Tensor II FTIR spectrometer (Bruker) and in situ reflection reaction (Fig. 1). The catalyst was loaded in the reaction chamber. The real-time FT-IR spectrum after heat treatment was utilized as background. Because of the detection sensitivity of the in situ FT-IR measurement, the concentration in the activity test (ppb level) is too low to be detected. Therefore, $50 \mathrm{ppm}$ of NO was introduced into the reactor. The reaction gas $(50 \mathrm{~mL} / \mathrm{min} \mathrm{NO}$, $50 \mathrm{~mL} / \mathrm{min} \mathrm{O}_{2}$ ) was then passed into the reaction chamber. After 20 min of adsorption, the catalyst was irradiated with

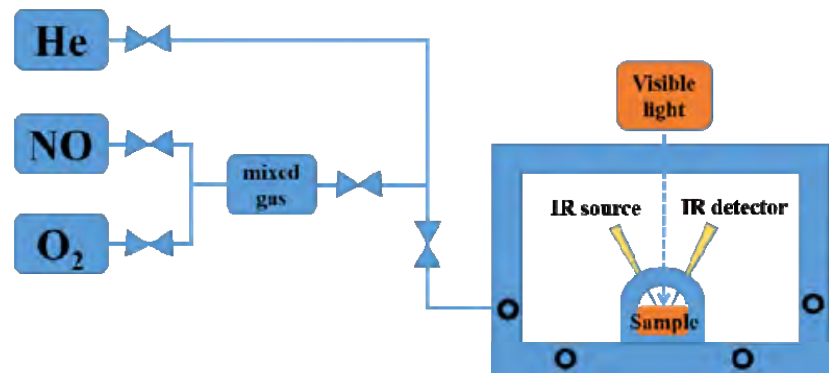

Fig. 1. Scheme of the in situ FT-IR apparatus equipped with a visible light source.

visible light for $20 \mathrm{~min}$. During the process of adsorption and reaction, the IR spectrum data were recorded every $2 \mathrm{~min}$. From the infrared scanning range of 4000-600 $\mathrm{cm}^{-1}, 2200-800$ $\mathrm{cm}^{-1}$ can be used to analyze the process of Bi-BiOI adsorption and photocatalytic oxidation of NO.

\section{Results and discussion}

\subsection{Phase and composition}

Fig. 2 shows the XRD patterns of $\mathrm{BiOI}$ and $\mathrm{Bi} / \mathrm{BiOI}-X(X=1$, $2,3,5$ ). It can be observed that the diffraction peaks of BiOI belong to tetragonal phase BiOI (JCPDS-ICDD Card No. 10-0445). With the increased addition of the $\mathrm{NaBH}_{4}$ reductant, the diffraction peaks of the Bi element (JCPDS-ICDD Card No. 44-1246) begin to appear and the intensity is gradually intensified. These results indicate that part of the $\mathrm{Bi}^{3+}$ in $\mathrm{BiOI}$ is in situ reduced to elemental $\mathrm{Bi}$ by $\mathrm{NaBH}_{4}$ in the solvent thermal treatment process. The metallic $\mathrm{Bi}$ content is increased with increasing reductant quantity. The decrease in the diffraction intensity of $\mathrm{Bi} / \mathrm{BiOI}-\mathrm{X}$ can be ascribed to the partial transformation of BiOI to metallic $\mathrm{Bi}$.

Fig. 3(a) shows the XPS spectra of the samples, which indicate that elemental $\mathrm{Bi}, \mathrm{O}, \mathrm{C}$, and I are contained on the surface of Bi/BiOI. Fig. 3(b) shows that the binding energy at $164.5 \mathrm{eV}$ (Bi $4 f_{5 / 2}$ ) and $159.2 \mathrm{eV}\left(\mathrm{Bi} 4 f_{7 / 2}\right.$ ) can be attributed to $\mathrm{Bi}^{3+}[46]$,

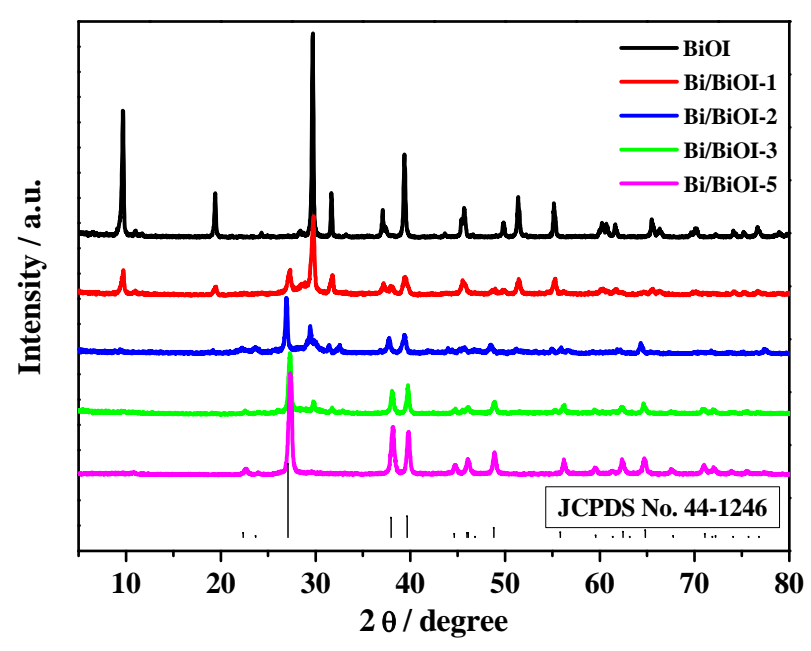

Fig. 2. XRD patterns of $\mathrm{Bi} / \mathrm{BiOI}-X(X=1,2,3,5)$. 

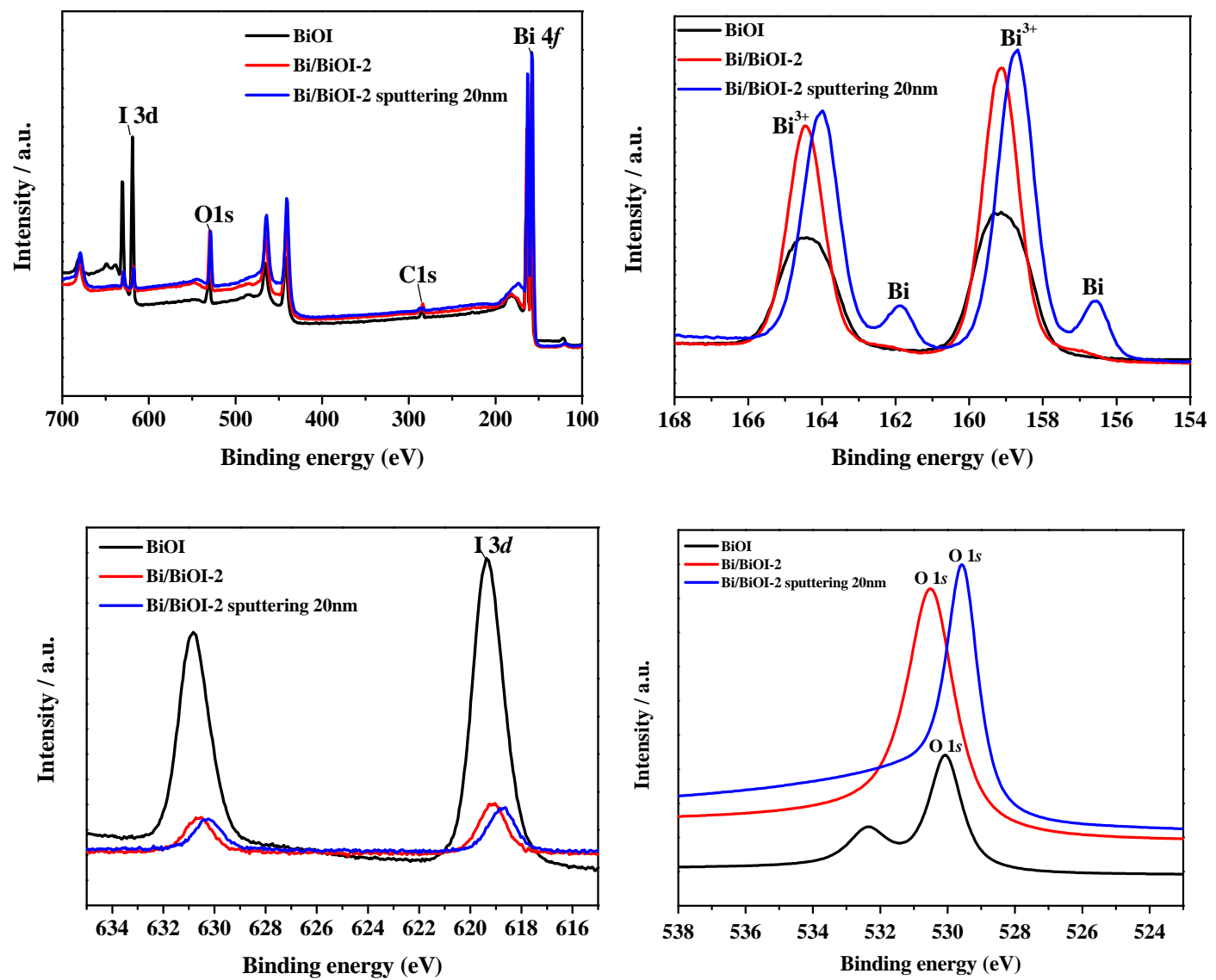

Fig. 3. XPS spectra for BiOI, Bi/BiOI-2, and Bi/BiOI-2 after sputtering. (a) Survey; (b) Bi 4f; (c) I $3 d$; (d) $01 s$

and the binding energy of $161.9 \mathrm{eV}\left(\mathrm{Bi} 4 f_{5 / 2}\right)$ and $156.8 \mathrm{eV}(\mathrm{Bi}$ $4 f_{7 / 2}$ ) belong to elemental Bi $[27,47]$. According to the XPS results, the molar ratio of metallic $\mathrm{Bi}$ is $2.12 \%$. This result is consistent with the XRD results, further confirming that elemental $\mathrm{Bi}$ is formed when the reductant is used. In Fig. 3(c), two dominant peaks located at 630.9 and $619.5 \mathrm{eV}$ can be assigned to I $3 d$. In Fig. 3d, the peak at $530.3 \mathrm{eV}$ belongs to the $\mathrm{Bi}-\mathrm{O}$ bond $[48,49]$.

\subsection{Morphology and structure}

Figs. 4(a) and 4(b) show the SEM images of BiOI and

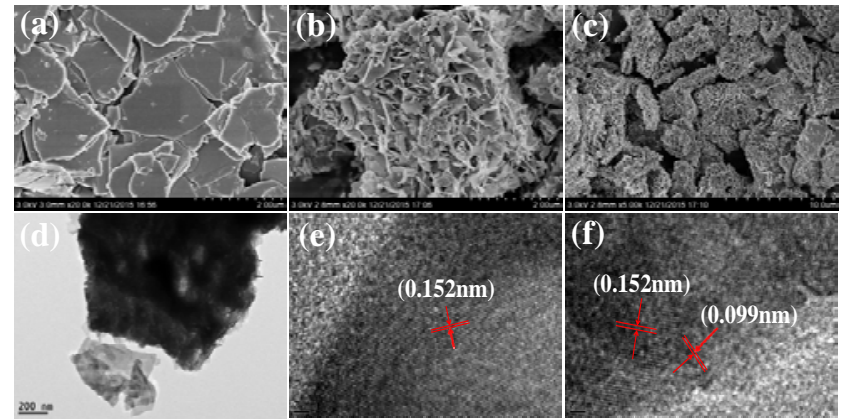

Fig. 4. SEM images of (a) BiOI and (b,c) Bi/BiOI-2; (d) TEM image of $\mathrm{Bi} / \mathrm{BiOI}-2$; HRTEM images of (e) BiOI and (f) Bi/BiOI-2.
Bi/BiOI-2. Fig. 4(a) shows that BiOI is composed by stacked nanosheets. It can be clearly observed from Fig. 4(b) that $\mathrm{Bi} / \mathrm{BiOI}-2$ is hierarchically assembled by nanosheets, forming a superstructure. Fig. 4(c) shows that the self-assembled Bi/BiOI has a sponge-like 3D stereostructure. The TEM image (Fig. $4(\mathrm{~d})$ ) further demonstrates that $\mathrm{Bi} / \mathrm{BiOI}$ is self-assembled by thin-layer nanosheets. Figs. 4(e) and 4(f) show the HRTEM image of a single nanosheet. The lattice spacing $(0.152$ and $0.099 \mathrm{~nm}$ ) can be observed, corresponding to the ( 006 6 crystal plane of $\mathrm{BiOI}$ and the $\left(\begin{array}{lll}0 & 0 & 12\end{array}\right)$ plane of $\mathrm{Bi}[50,51]$.

Figs. 5(a) and 5(b) show the $\mathrm{N}_{2}$ adsorption-desorption isotherms and corresponding pore sizes of $\mathrm{BiOI}$ and $\mathrm{Bi} / \mathrm{BiOI}-X$. According to the Brunauer-Deming-Deming-Teller (BDDT) classification, the above samples belong to isotherm IV, indicating the presence of mesopores in the sample (Fig. 5(a)). The hysteresis loop of the adsorption-desorption isotherms can be classified as H3 (classified by IUPAC), indicating the presence of fractured pores from the stacking of nanosheets, consistent with SEM results (Fig. 4). From the pore-size distribution curve (Fig. 5(b)), the pore sizes of the samples BiOI and $\mathrm{Bi} / \mathrm{BiOI}-X$ are all located at 2 to $100 \mathrm{~nm}$, which further confirms the formation of mesoporous/microporous structure (2-100 nm). As the reductant quantity is increased to $2 \mathrm{mmol}$, the hierarchical stacking of nanosheets accounts for the formation of large pores and enlarged specific surface areas. Table 1 shows the 

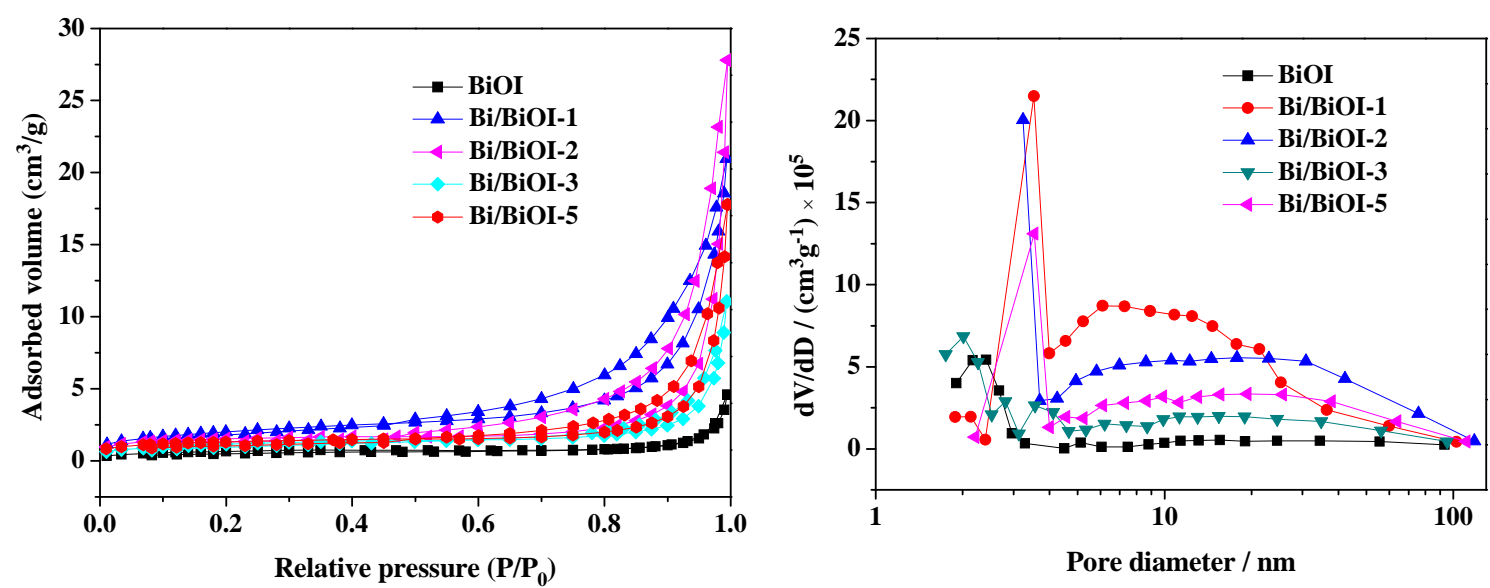

Fig. 5. (a) $\mathrm{N}_{2}$ adsorption-desorption isotherms and (b) pore-size distribution curves of BiOI and $\mathrm{Bi} / \mathrm{BiOI}-X(X=1,2,3,5)$.

specific surface area and pore volume of the samples; they were increased from $2.3-7.2 \mathrm{~m}^{2} / \mathrm{g}$ and $0.007-0.043 \mathrm{~cm}^{3} / \mathrm{g}$, respectively, as the reductant quantity was increased to 2 mmol. However, when more than $2 \mathrm{mmol}$ was used, the specific surface area and pore size of the samples were slightly reduced.

\subsection{Light absorption and the effect of oxygen vacancy}

Fig. 6(a) displays the UV-vis diffuse reflectance spectra of $\mathrm{BiOI}$ and $\mathrm{Bi} / \mathrm{BiOI}-X$. We can observe that the BiOI already shows extended light absorption up to $650 \mathrm{~nm}$. Furthermore, the band gap of the BiOI estimated from the intercept of the tangent to the $(\alpha h v)^{1 / 2}$ vs. photoenergy (Fig. 6(b)) plot is 1.80 $\mathrm{eV}$, which causes BiOI to easily absorb visible light in a wide range. Solid-state EPR spectra are recorded to demonstrate the existence of the oxygen vacancies. As shown in Fig. 6(c), BiOI has a strong signal peak at $g=2.001$ in the dark, which is attributable to the existence of oxygen vacancies [52,53]. At the same time, the signals of $\mathrm{Bi} / \mathrm{BiOI}-2$ become stronger, indicating the increased production of oxygen vacancies. The production of oxygen vacancies in BiOI can be ascribed to the reductive effect of $\mathrm{NaBH}_{4}$ [40]. Under visible light irradiation, the intensity of the EPR signal on BiOI and $\mathrm{Bi} / \mathrm{BiOI}-X$ is enhanced, indicating higher electron mobility and lower electron recombination rates [54,55]. The density of states (DOS) of intrinsic BiOI and defective BiOI (Fig. 6(d)) are calculated to further reveal the role of oxygen vacancies. Significant intermediate levels appeared under the conduction band of the BiOI, implying that the oxygen vacancies contribute to the formation of multiple intermediate levels, which could promote electron transition

Table 1

Surface area, pore parameter, and NO removal ratio of the samples.

\begin{tabular}{lccc}
\hline Sample & $A_{\text {BET }}\left(\mathrm{m}^{2} / \mathrm{g}\right)$ & Pore volume $\left(\mathrm{cm}^{3} / \mathrm{g}\right)$ & $\eta(\mathrm{NO})(\%)$ \\
\hline $\mathrm{BiOI}$ & 2.3 & 0.007 & 3.0 \\
$\mathrm{Bi} / \mathrm{BiOI}-1$ & 7.2 & 0.032 & 19.9 \\
$\mathrm{Bi} / \mathrm{BiOI}-2$ & 5.0 & 0.043 & 40.8 \\
$\mathrm{Bi} / \mathrm{BiOI}-3$ & 4.1 & 0.017 & 32.3 \\
$\mathrm{Bi} / \mathrm{BiOI}-5$ & 4.3 & 0.028 & 25.6 \\
\hline
\end{tabular}

from the valence band (VB) to conduction band (CB) through intermediate levels under visible light irradiation $[28,56]$. With the increase in reductant quantity, the reduction ability of $\mathrm{NaBH}_{4}$ is enhanced, and thus, a greater amount of elemental Bi and oxygen vacancies is produced [57-59]. As a result, $\mathrm{Bi} / \mathrm{BiOI}-X$ exhibits full absorption in the visible region owing to the SPR effect of elemental $\mathrm{Bi}$, consistent with the change in color of the sample from brick-red to black $[18,20,28]$.

\subsection{Charge carrier separation and highly enhanced visible light photocatalytic activity}

Fig. 7(a) shows the photoluminescence (PL) spectra for all the samples. The PL intensity of $\mathrm{Bi} / \mathrm{BiOI}-X$ is significantly lower than that of BiOI, because elemental $\mathrm{Bi}$ in $\mathrm{Bi} / \mathrm{BiOI}-X$ induces the electromagnetic field through the SPR effect, which could promote the separation of photogenerated charge carriers [60]. Fig. $7 \mathrm{~b}$ shows the visible light photocatalytic NO removal ratio by $\mathrm{BiOI}$ and $\mathrm{Bi} / \mathrm{BiOI}-X$ under visible light. BiOI exhibits little NO removal ratio after 30-min irradiation because of rapid recombination of photogenerated charge carriers $[61,62]$. When the reductant quantity is increased from 1 to $5 \mathrm{mmol}$, the NO removal ratio of $\mathrm{Bi} / \mathrm{BiOI}-2$ is increased to $40.8 \%$, which is much more efficient than that of BiOI (5.0\%) without 3D structure [28]. Although Bi/BiOI-1 has a higher BET surface area, the electronic structure of $\mathrm{Bi} / \mathrm{BiOI}-1$ has not been fully optimized; therefore, it does not exhibit higher photocatalytic performance. The highly enhanced visible light photocatalysis of $\mathrm{Bi} / \mathrm{BiOI}-2$ can be ascribed to the synergistic effects of oxygen vacancies and metallic Bi. On the one hand, oxygen vacancies favor the transition of electrons from the valence band to an intermediate level and then to the conduction band under visible light irradiation $[28,56]$. Multiple intermediate levels can be conducive to the transition of electrons and the separation of photogenerated electron-hole pairs (Fig. 7(a)). On the other hand, the SPR effect of elemental Bi can improve visible light absorption efficiency (Fig. 6(a)) and promote the separation of photogenerated electron-hole pairs. Bi/BiOI-2 exhibits strong 

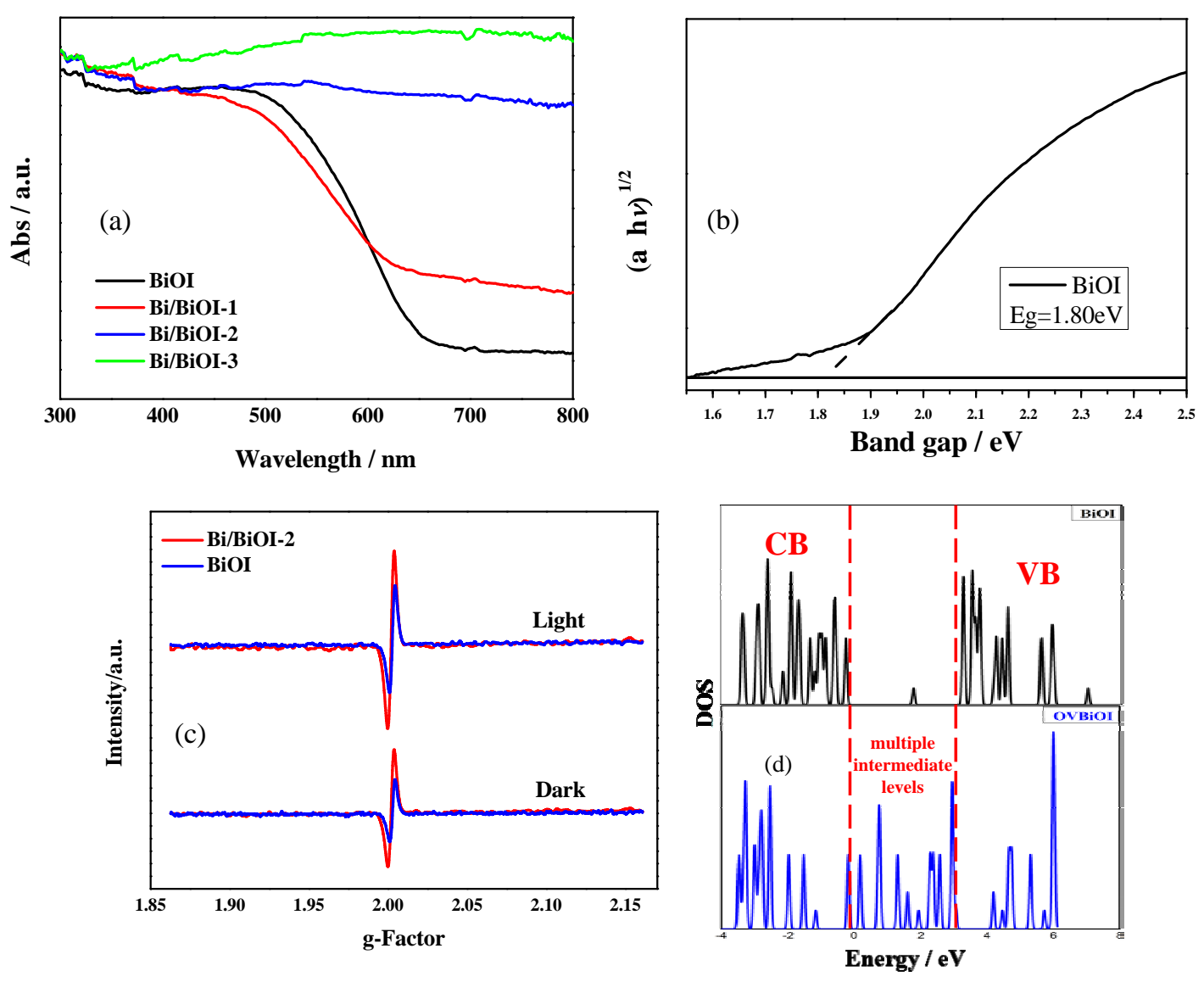

Fig. 6. (a) UV-vis DRS of BiOI and Bi/BiOI-X; (b) Band gap determination; (c) EPR spectra of BiOI and Bi/BiOI-2; (d) Density of states (DOS) of BiOI and $\mathrm{BiOI}$ with oxygen vacancies (OV-BiOI).

light absorption and higher photogenerated charge separation efficiency. However, the specific surface area decreased and visible light photocatalytic performance declined when more than $2 \mathrm{mmol}$ of reductant $\mathrm{NaBH}_{4}$ was added, through the collapse of the sponge-like 3D structure of Bi/BiOI- $X$.

\subsection{Electron delivery and photocatalysis mechanism}

To further recover the vital roles of elemental $\mathrm{Bi}$ in $\mathrm{Bi} / \mathrm{BiOI}-2$, we used the DFT to calculate the electronic structure of the catalysts. Fig. 8(a) shows the charge difference distribution of elemental Bi on BiOI. Blue and yellow stand for charge accumulation and depletion, respectively. Evidently, the Bi-O layer of BiOI obtains the electrons from elemental $\mathrm{Bi}$ and becomes the photo-active sites. The electronic location function (ELF) (Fig. 8(b)) demonstrates the existence of a strong covalent interaction between the elemental $\mathrm{Bi}$ and the $\mathrm{Bi}-\mathrm{O}$ layer, forming a channel for hot electrons of elemental Bi to be transferred from metallic Bi to BiOI. To explore how the excited electrons of $\mathrm{Bi}$ can be easily transferred to the $\mathrm{Bi}-\mathrm{O}$ layer, the potentials of $\mathrm{Bi} / \mathrm{BiOI}$ and $\mathrm{BiOI}$ were calculated. As is shown in Fig. 8(c), the potential of elemental $\mathrm{Bi}$ is higher than that of the Bi-O layer. The energy barrier between the Bi layer and Bi-O layer is $17.80 \mathrm{eV}$. Charge transfer from the Bi layer to Bi-O layer is easier than the transfer from the $\mathrm{Bi}-\mathrm{O}$ layer to $\mathrm{Bi}$ layer. Under visible light irradiation, excited hot electrons from elemental $\mathrm{Bi}$ can easily cross the barrier and transfer to the adjacent Bi-O layer. From another aspect, we calculate the density of states (DOS) of Bi/BiOI and BiOI (Figs. 8(d) and 8€) and the partial density of state (PDOS) of elemental Bi (Fig. 8(f)). Clearly, the valence-band maximum (VBM) of $\mathrm{Bi} / \mathrm{BiOI}$ is significantly extended by the contribution of the orbital from elemental $\mathrm{Bi}$. This may be ascribed to the SPR effect of elemental Bi, driving the electrons of BiOI to a higher excited state to accumulate at the VBM [63]. This is beneficial for promoting the generation of photogenerated charge carriers.

Fig. 9(a) shows the hydroxyl radical $(\bullet \mathrm{OH})$ and superoxide radical $\left(\bullet \mathrm{O}_{2}^{-}\right)$signals in $\mathrm{BiOI}$ and $\mathrm{Bi} / \mathrm{BiOI}-2$, which is produced from water oxidation by electron-holes and oxygen reduced by free electrons. The $\bullet \mathrm{OH}$ and $\bullet \mathrm{O}_{2}{ }^{-}$signals of $\mathrm{Bi} / \mathrm{BiOI}-2$ are higher than that of pure BiOI because of enhanced charge separation and transfer. The increased production of reactive radicals is responsible for the highly enhanced photocatalytic activity of $\mathrm{Bi} / \mathrm{BiOI}$. Notwithstanding the amount of radical production, the band structure and optical absorption of $\mathrm{Bi} / \mathrm{BiOI}-2$ have been improved by oxygen vacancy and metallic $\mathrm{Bi}$. Thus, the photocatalytic performance of $\mathrm{Bi} / \mathrm{BiOI}-2$ is significantly higher than that of BiOI.

Based on various experimental and theoretical results, the corresponding photocatalytic mechanism of metallic 

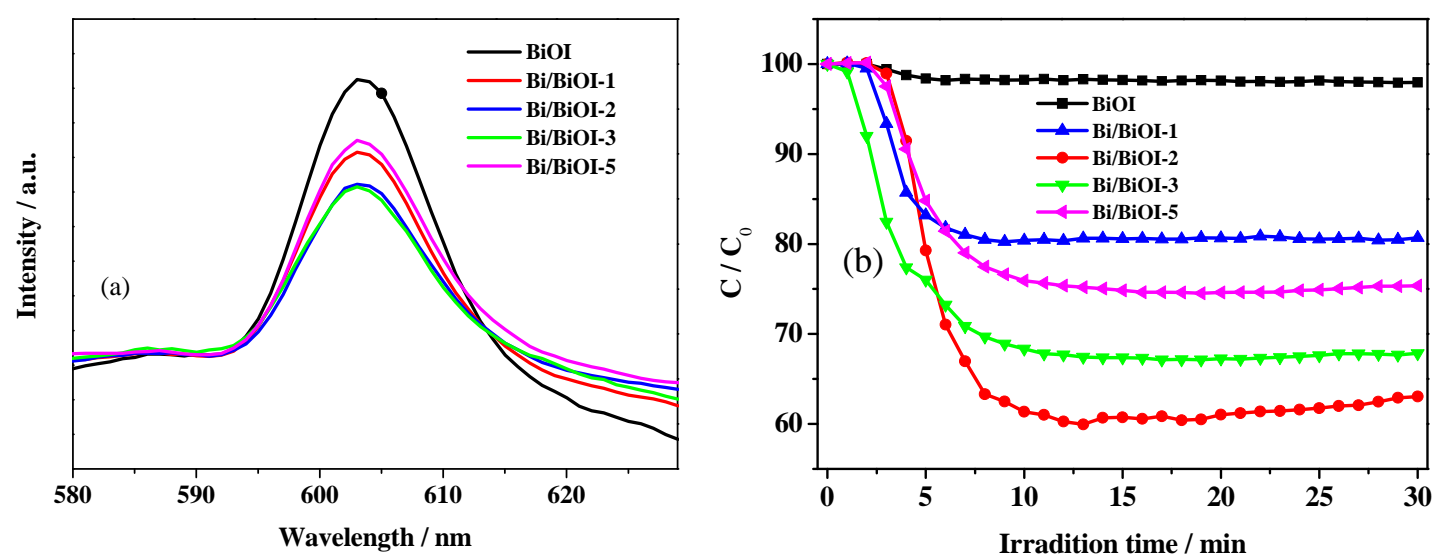

Fig. 7. (a) PL spectra of Bi/BiOI- $X(X=1,2,3,5)$; (b) Visible light photocatalytic activity for NO removal.
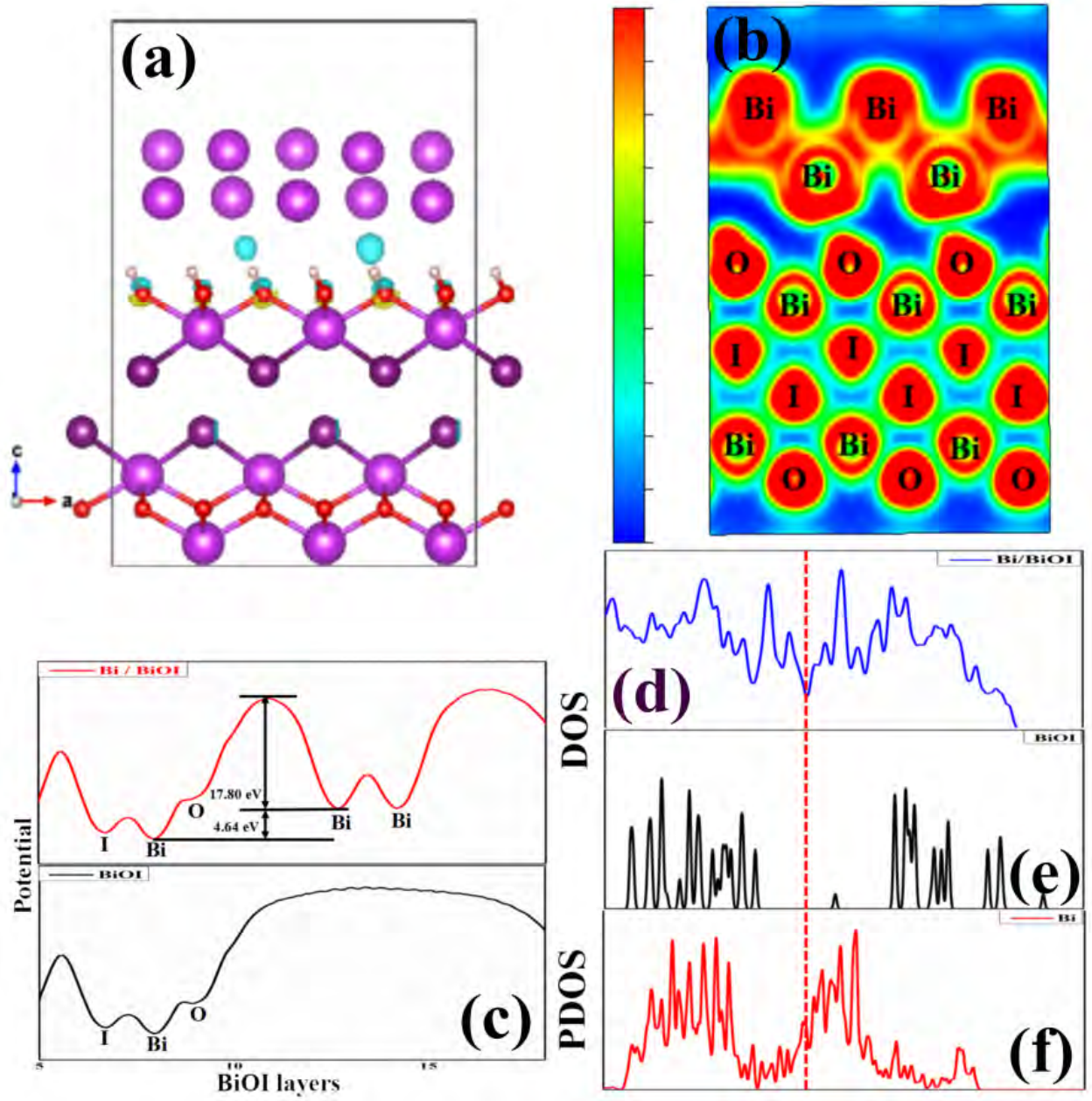

Fig. 8. (a) Charge difference distribution between $\mathrm{Bi}$ atoms and $\mathrm{Bi}-\mathrm{O}$ layers of $\mathrm{Bi} / \mathrm{BiOI}$ (charge accumulation is in blue and depletion is in yellow); (b) Electronic location function (ELF); (c) Electrostatic potential; (d) Density of state of Bi/BiOI; (e) Density of state of BiOI; (f) Projected density of states (PDOS) of Bi atom in elemental Bi layers.

Bi@defective BiOI was proposed as shown in Fig. 10. The oxygen vacancies in BiOI induce the formation of multiple intermediate levels (Fig. 6(d)), allowing direct transition from VB to intermediate levels under visible light irradiation. This also enhances defective BiOI with visible photocatalytic activity, because the electrons from the intermediate levels can be fur- ther excited to the $\mathrm{CB}$ of BiOI.

Moreover, the introduction of elemental $\mathrm{Bi}$ in BiOI exerts a significant promotion effect on the photocatalytic performance in visible light (Fig. 7(b)). First, the SPR effect of elemental Bi produces an electromagnetic field and promotes defective BiOI with electrons in a higher excited state, accumulating at the 

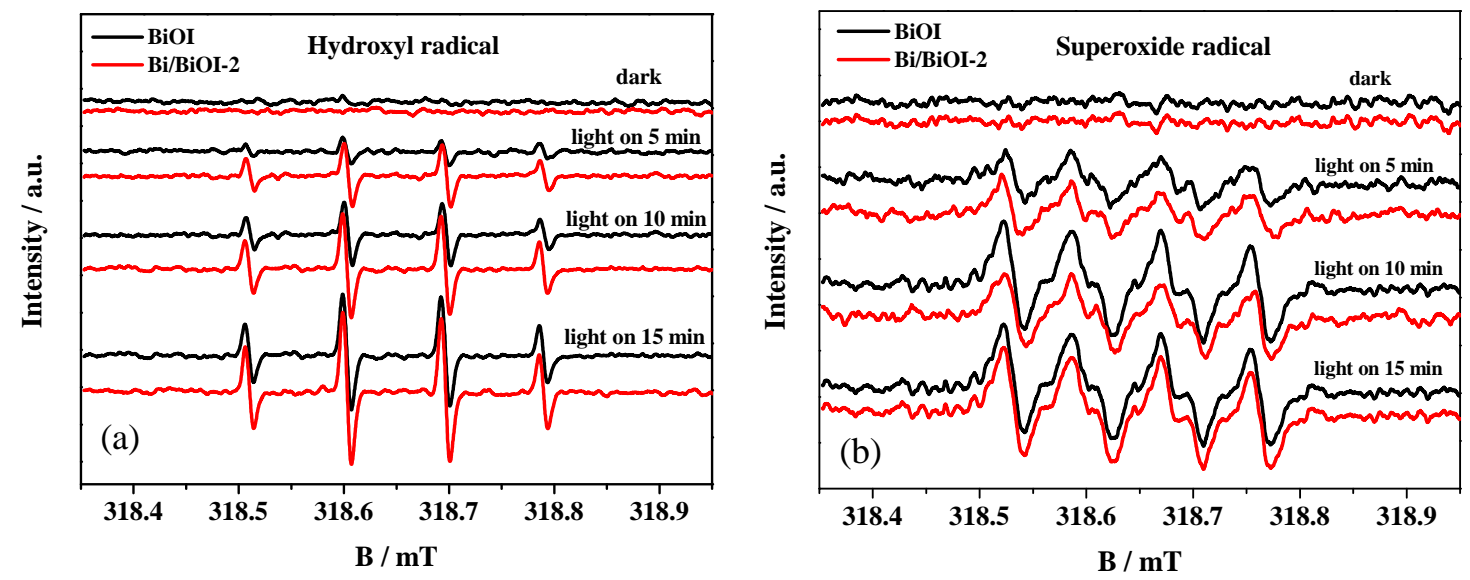

Fig. 9. ESR spectra of (a) hydroxyl radicals and (b) superoxide radicals of BiOI and Bi/BiOI-2.

VBM, which facilitate the separation of the photogenerated electron-hole pairs. Next, the hot electrons of elemental $\mathrm{Bi}$ transfer to the Bi-O layer, and the electrons from the intermediate levels transfer to elemental Bi simultaneously to maintain neutrality of elemental $\mathrm{Bi}$, promoting the electron-hole pair separation of BiOI and radical production. Hence, by in situ reduction of $\mathrm{Bi}^{3+}$ to elemental $\mathrm{Bi}$ and the creation of defects on the hierarchical microsheet structure of BiOI, photocatalytic performance can be significantly improved.

\subsection{In situ FT-IR investigation on the photocatalytic reaction mechanism}

Fig. 11 displays the in situ FT-IR spectra of NO adsorption in the dark and photocatalytic reaction processes on the surface of $\mathrm{Bi} / \mathrm{BiOI}-2$ under visible light irradiation. Table 2 summarizes the assignment of the corresponding absorption bands. Under dark conditions, the absorption peak of nitrates $\left(1048 \mathrm{~cm}^{-1}\right)$ is noted after adsorption equilibrium. This could be attributed to oxygen vacancies in $\mathrm{BiOI}$, which activate adsorbed $\mathrm{O}_{2}$ to form

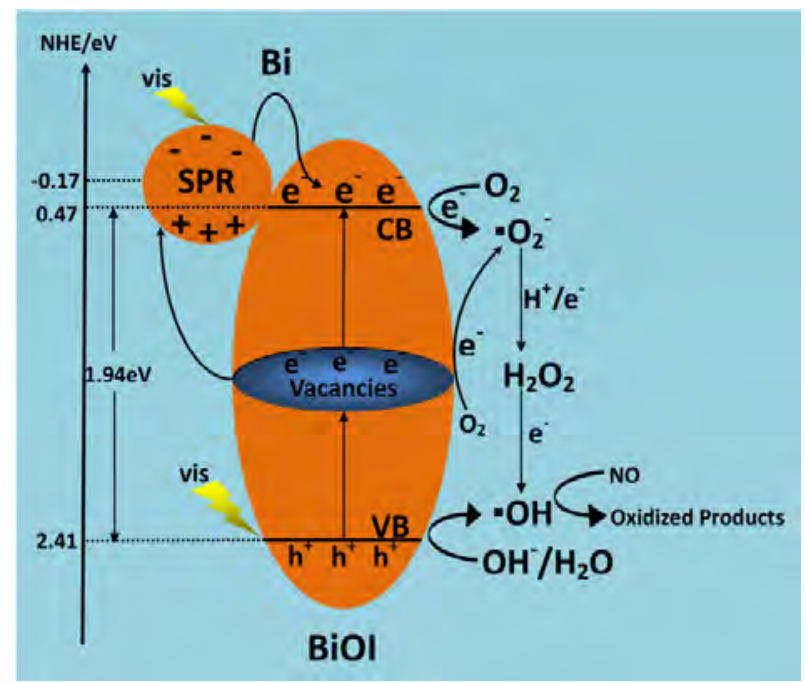

Fig. 10. Mechanism of plasmonic photocatalysis on Bi/BiOI-2. superoxide radical $\bullet \mathrm{O}_{2}{ }^{-}$, oxidizing the $\mathrm{NO}$ to nitrates [64]. A proposed workable mechanism of $\mathrm{NO}$ adsorption is illustrated in Scheme 1.

After visible light irradiation, enhanced absorption bands of the $\mathrm{NO}_{2}$ polymer $\left(\mathrm{N}_{2} \mathrm{O}_{4}\right)$, nitrites (at 1174 and $\left.1327 \mathrm{~cm}^{-1}\right)$, and nitrates (at 809, 841, 1000, 1015, 1048, 1445, and $1482 \mathrm{~cm}^{-1}$ ) can be detected. This is indicative of the active species generated under visible light, which induces the photocatalytic NO oxidation, consistent with the transient decrease in NO concentration under visible light for the fi $\sim 2$ min in Fig. 7(c). As the

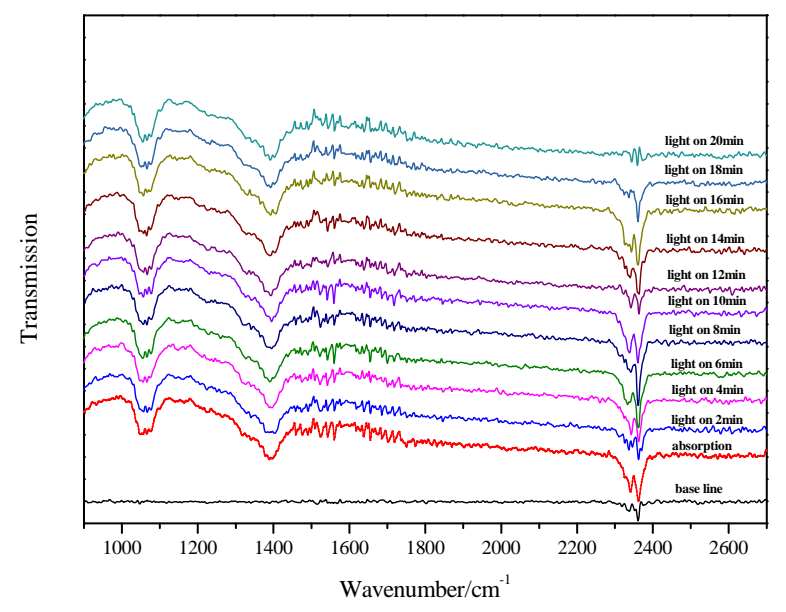

Fig. 11. In situ FT-IR spectra of photocatalytic NO oxidation process over $\mathrm{Bi} / \mathrm{BiOI}-2$ under visible light irradiation.

\section{Table 2}

Assignments of the IR bands observed during photocatalytic NO oxidation processes over $\mathrm{Bi} / \mathrm{BiOI}-2$ under visible light irradiation.

\begin{tabular}{lcc}
\hline Wavenumber $\left(\mathrm{cm}^{-1}\right)$ & Band assignment & Ref. \\
\hline 809,841 & $\mathrm{NO}_{3}{ }^{-}$ & {$[58]$} \\
1000 & Bridging $\mathrm{NO}_{3}{ }^{-}$ & {$[60]$} \\
1015,1048 & Bidentate $\mathrm{NO}_{3}-$ & {$[58,60]$} \\
1174 & Chelate $\mathrm{NO}_{2}^{-}$ & {$[60]$} \\
1274 & $\mathrm{~N}_{2} \mathrm{O}_{4}$ & {$[58]$} \\
1327 & $\mathrm{NO}_{2}-$ & {$[58]$} \\
1445,1482 & $B i d e n t a t e \mathrm{NO}_{3}^{-}$ & {$[58]$} \\
1726 & $\mathrm{~N}_{2} \mathrm{O}_{4}$ & {$[58]$} \\
\hline
\end{tabular}




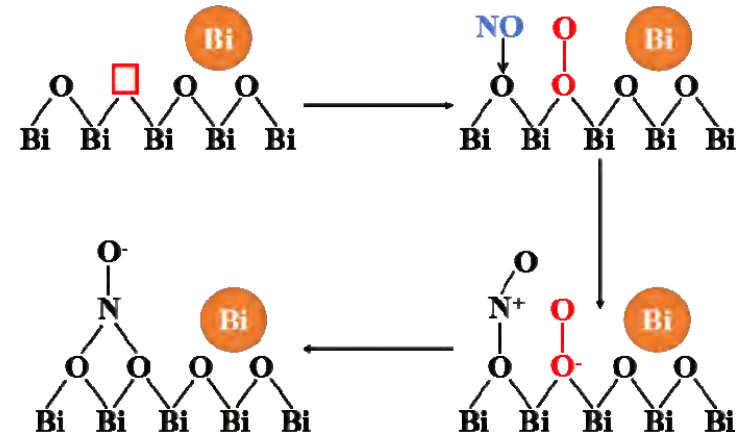

Scheme 1. A possible mechanism of NO adsorption on Bi/BiOI-2.

photocatalytic reaction progresses, the absorption peaks of different forms of nitrites and nitrates are generated, which may be originated from the NO adsorbed at diverse locations on the surface of the photocatalyst (as shown in Scheme 2). In addition, nitrites and nitrates tend to be oxidized to the more stable state by superoxo species [65]. Hence, the absorption peak at $1015 \mathrm{~cm}^{-1}$ (bidentate $\mathrm{NO}_{3}^{-}$) gradually shifts to 1000 $\mathrm{cm}^{-1}$ (bridging $\mathrm{NO}_{3}^{-}$) with illumination time (as shown in Scheme 3) [68-72].

\section{Conclusions}

The plasmonic metallic Bi@defective BiOI with 3D hierarchal structure was constructed by reduction of partial $\mathrm{Bi}^{3+}$ in BiOI. The photocatalytic removal of NO through visible light on plasmonic metallic Bi@defective BiOI was greatly improved. This is primarily attributed to the synergistic effects of oxygen vacancies and metallic Bi. The electrons from the valence band tend to accumulate at vacancies as well as intermediate levels so that the increasing charge density would cause oxygen accumulated at those sites to easily form superoxide radicals and hydroxyl radicals, which are the main active species that oxidize NO into final products. The surface plasmon resonance effect of elemental Bi enables the improvement in visible light absorption efficiency and the promotion of the charge carriers. The reaction process of photocatalytic NO oxidation was systematically studied by in situ FT-IR. NO was adsorbed on the surface of photocatalysts at different locations and would be
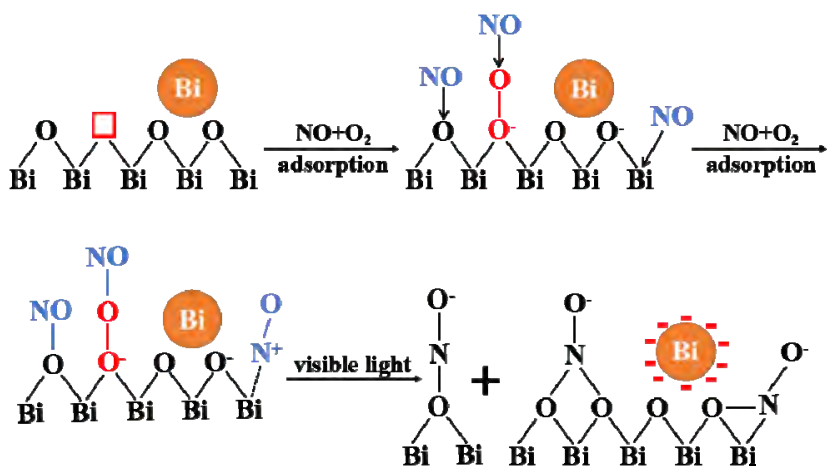

Scheme 2. A possible mechanism of photocatalytic NO oxidation on $\mathrm{Bi} / \mathrm{BiOI}-2$.

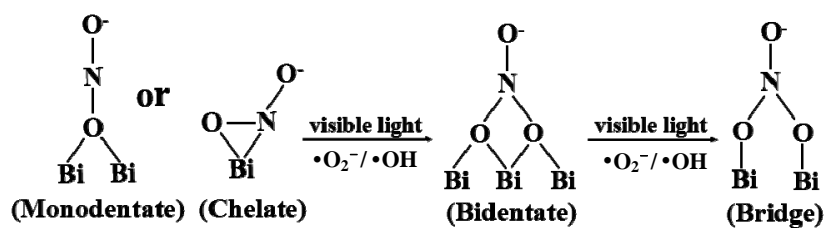

Scheme 3. A possible mechanism of nitrates oxidation on $\mathrm{Bi} / \mathrm{BiOI}-2$.

oxidized to produce diverse forms of nitrite and nitrate. Combining DFT calculations and the reaction process, the relevant reaction mechanism of photocatalytic NO oxidation on metallic Bi@defective BiOI was proposed involving the synergistic roles of multiple intermediate levels excited by oxygen defects and metallic Bi. This study provides a new method to understand the photocatalytic reaction mechanism of heterojunction photocatalyst composites by elemental semi-metals and semiconductors, as well as the mechanisms of the SPR effect and multiple intermediate levels in cooperatively enhancing photocatalytic performance.

\section{Acknowledgments}

The authors acknowledge the AM-HPC in Suzhou, China for computational support.

\section{References}

[1] L. Zhang, W. Wang, J. Yang, Z. Chen, W. Zhang, L. Zhou, S. Liu, Appl. Catal. A, 2006, 308, 105-110.

[2] W. Cui, J. Li, Y. Sun, H. Wang, G. Jiang, S. C. Lee, F. Dong, Appl. Catal. $B, 2018,237,938-946$.

[3] Z. Ni, W. Zhang, G. Jiang, X. Wang, Z. Lu, Y. Sun, X. Li, Y. Zhang, F. Dong, Chin. J. Catal., 2017, 38, 1174-1183.

[4] Z. Y. Jiang, X. H. Liang, H. L. Zheng, Y. Y. Liu, Z. Y. Wang, P. Wang, X. Y. Zhang, X. Y. Qin, Y. Dai, M. H. Wangbo, B. B. Huang, Appl. Catal. B, 2017, 219, 209-215.

[5] H. Liu, H. T. Ma, X. Z. Li, W. Z. Li, M. Wu, X. H. Bao, Chemosphere, 2003, 50, 39-46.

[6] G. Tian, Y. Chen, W. Zhou, K. Pan, Y. Dong, C. Tian, H. Fu, J. Mater. Chem., 2011, 21, 887-892.

[7] J. Bi, L. Wu, J. Li, Z. Li, X. Wang, X. Fu, Acta Mater., 2007, 55, 4699-4705.

[8] L. Zhang, T. Xu, X. Zhao, Y. Zhu, Appl. Catal. B, 2010, 98, 138-146.

[9] H. Cheng, B. Huang, K. Yang, Z. Wang, X. Qin, X. Zhang, Y. Dai, ChemPhysChem, 2010, 11, 2167-2173.

[10] L. Y. Ding, R. J. Wei, H. Chen, J. C. Hu, J. L. Li, Appl. Catal. B, 2015, 172-173, 91-99.

[11] W. Zhang, X. Liu, X. Dong, F. Dong, Y. Zhang, Chin. J. Catal., 2017, 38, 2030-2038.

[12] A. Luz, C. Feldmann, Solid State Sci., 2011, 13, 1017-1021.

[13] J. Li, X. Dong, Y. Sun, W. Cen, F. Dong, Appl. Catal. B, 2018, 226, 269-277.

[14] Y. Sun, X. Xiao, X. Dong, F. Dong, W. Zhang, Chin. J. Catal., 2017, 38, 217-226.

[15] Y. Huang, D. Zhu, Q. Zhang, Y. Zhang, J. Cao, Z. Shen, W. Ho, S. C. Lee, Appl. Catal. B, 2018, 234, 70-78.

[16] M. Ou, F. Dong, W. Zhang, Z. Wu, Chem. Eng. J., 2014, 255, 650-658.

[17] P. Chen, F. Dong, M. Ran, J. Li, Chin. J. Catal., 2018, 39, 619-629. 


\section{Graphical Abstract}

Chin. J. Catal., 2019, 40: 826-836 doi: 10.1016/S1872-2067(18)63195-X

\section{Synergistic integration of metallic $\mathrm{Bi}$ and defects on $\mathrm{BiOI}$ :} Enhanced photocatalytic NO removal and conversion pathway

Minglu Sun, Wendong Zhang, Yanjuan Sun, Yuxin Zhang, Fan Dong * Chongqing Technology and Business University; Chongqing Normal University; Chongqing University; Southwest Petroleum University

Intermediate level induced by vacancies could promote the electron transition, prohibit charge recombination, and produce more main active species. The surface plasmon resonance effect of elemental Bi improves visible light absorption efficiency and charge carriers separation. The synergistic integration of metallic Bi and defects could enhance photocatalytic performance of BiOI.

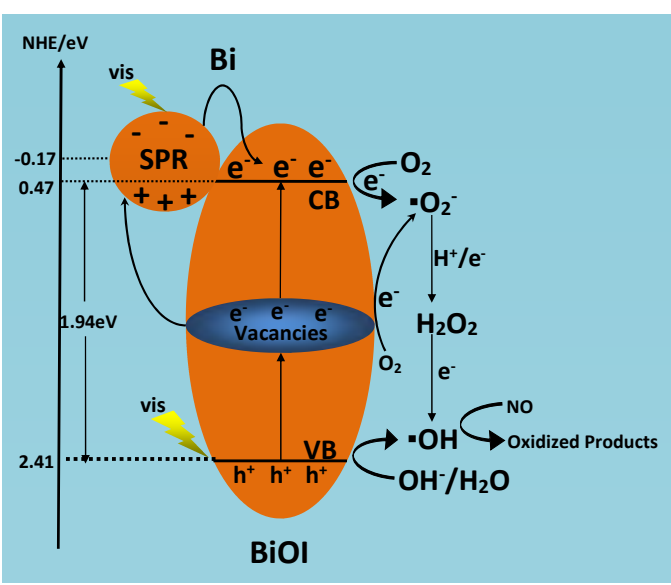

[38] H. Nakai, J. Heyd, G. E. Scuseria, J. Comput. Chem. Jpn., 2006, 5, 7-18.

[39] G. Kresse, J. Furthmüller, Comput. Mater. Sci., 1996, 6, 15-50.

[40] G. Kresse, J. Furthmüller, Phys. Rev. B, 1996, 54, 11169-11186.

[41] J. P. Perdew, K. Burke, M. Ernzerhof, Phys. Rev. Lett., 1996, 77, 3865-3868.

[42] P. E. Bloechl, Phys. Rev. B, 1994, 50, 17953-17979.

[43] G. Kresse, D. Joubert, Phys. Rev. B, 1999, 59, 1758-1775.

[44] S. K. Bhatia, A. L. Myers, Langmuir, 2006, 22, 1688-1700.

[45] R. C. Lochan, M. Head-Gordon, Phys. Chem. Chem. Phys., 2006, 8, 1357-1370.

[46] J. Jiang, L. Zhang, H. Li, W. He, J. J. Yin, Nanoscale, 2013, 5, 10573-10581.

[47] Y. Fujimoto, in: M. Grishin ed., Advances in Solid-State Lasers: Development and Applications, Intech, 2010, Chapter 2, 25-44.

[48] F. Dong, Y. Sun, M. Fu, Z. Wu, S. C. Lee, J. Hazard. Mater., 2012, 26, 219-220.

[49] Z. Ai, W. Ho, S. Lee, L. Zhang, Environ. Sci. Technol,, 2009, 43, 4143-4150.

[50] X. Xiao, W. Zhang, J. Mater. Chem., 2010, 20, 5866-5870.

[51] L. Ye, J. Chen, L. Tian, J. Liu, T. Peng, K. Deng, L. Zan, Appl. Catal. B, 2013, 130-131, 1-7.

[52] I. Nakamura, N. Negishi, S. Kutsuna, T. Ihara, S. Sugihara, K. Takeuchi, J. Mol. Catal. A, 2000, 161, 205-212.

[53] L. Ye, L. Zan, L. Tian, T. Peng, J. Zhang, Chem. Commun., 2011, 47, 6951-6953.

[54] Z. Diwu, J. W. Lown, Free Radic. Biol. Med., 1993, 14, 209-215.

[55] M. Ikeya, Nature, 1975, 255, 48-50.

[56] T. Stauber, N. M. R. Peres, F. Guinea, Phys. Rev. B, 2007, 76, 205423/1-205423/10.

[57] J. Ke, J. Liu, H. Sun, H. Zhang, X. Duan, P. Liang, X. Li, M. O. Tade, S. Liu, S. Wang, Appl. Catal. B, 2017, 200, 47-55.

[58] Q. Zhao, Y. Ren, X. Li, Y. Shi, Mater. Res. Bull., 2016, 83, 396-399.

[59] F. Zhang, X. Li, Q. Zhao, A. Chen, J. Phys. Chem. C, 2016, 120, 19113-19123.

[60] Y. Sun, Z. Zhao, F. Dong, W. Zhang, Phys. Chem. Chem. Phys., 2015, 17, 10383-10390.

[61] G. L. Huang, Y. Zhu, J. Phys. Chem. C, 2007, 111, 11952-11958. 
[62] R. Shi, G. Huang, J. Lin, Y. Zhu, J. Phys. Chem. C, 2009, 113, 19633-19638.

[63] H. Li, J. Shang, H. Zhu, Z. Yang, Z. Ai, L. Zhang, ACS Catal., 2016, 6, 8276-8285.

[64] J. Li, S. Yin, F. Dong, W. Cen, Y. Chu, ACS Appl. Mater. Interfaces, 2017, 9, 19861-19869.

[65] K. I. Hadjiivanov, Catal. Rev. Sci. Eng., 2000, 42, 71-144.

[66] J. C. S. Wu, Y. T. Cheng, J. Catal., 2006, 237, 393-404.

[67] L. Zhong, Y. Yu, W. Cai, X. Geng, Q. Zhong, Phys. Chem. Chem. Phys.,
2015, 17, 15036-15045.

[68] N. Tang, Y. Liu, H. Wang, Z. Wu, J. Phys. Chem. C, 2011, 115, 8214-8220.

[69] J. Laane, J. R. Ohlsen, Prog. Inorg. Chem., 1980, 27, 465-513.

[70] K. Hadjiivanov, V. Avreyska, D. Klissurski, T. Marinova, Langmuir, 2002, 18, 1619-1625.

[71] J. Valyon, W. K. Hall, J. Phys. Chem., 1993, 97, 1204-1212.

[72] X. Feng, W. Zhang, Y. Sun, H. Huang, F. Dong, Environ. Sci. Nano, 2017, 4, 604-612.

\title{
$\mathrm{BiOI}$ 上Bi单质和缺陷的协同作用: 增强的光催化NO去除和转化途径
}

\author{
孙明禄 ${ }^{\mathrm{a}}$, 张文东 ${ }^{\mathrm{b}}$, 孙艳娟, ${ }^{\mathrm{a}, \#}$, 张育新 ${ }^{\mathrm{c}}$, 董 帆 ${ }^{\mathrm{a}, \mathrm{d}, *}$ \\ a 重庆工商大学环境与资源学院催化与环境新材料重庆市重点实验室, 重庆400067 \\ $\mathrm{b}^{\mathrm{C}}$ 重庆师范大学科研处无机功能材料重庆市重点实验室, 重庆401331 \\ c 重庆大学材料科学与工程学院, 重庆 400044 \\ d 电子科技大学基础与前沿研究院环境科学与技术研究中心, 四川成都610500
}

\begin{abstract}
摘要: BiOI具有独特的层状结构及较窄的带隙, 是具有可见光响应的光催化剂. 然而, 高光生载流子复合率抑制了其光催 化活性. 大量研究表明, 氧缺陷不但是催化剂表面最具活性的位点, 而且可以通过减小禁带宽度扩大光响应范围. 与此同 时, 氧缺陷也可以作为光致电荷陷阱, 抑制电子-空穴复合, 并作为电荷转移到吸附物种的吸附位点. 金属的表面等离子体 共振 (SPR) 效应为半导体材料更高效的光吸收和利用提供了一条崭新的途径, 从而可以获得更好的太阳光转换和光催化效 率. 然而, SPR 效应和由氧缺陷引起的多个中间能级协同作用还未被探究. 本文研究了利用金属铋的SPR效应和引入缺陷 共同提高BiOI的光催化性能. 通过部分还原BiOI制备出具有较高可见光催化去除氮氧化物活性的Bi@缺陷型BiOI, 研究了 还原剂用量对 $\mathrm{Bi} @$ 缺陷型 $\mathrm{BiOI}$ 光催化性能的影响. 发现用 2 mmol还原剂 $\mathrm{NaBH}_{4}$ 制备的光催化剂( $\left.\mathrm{Bi} / \mathrm{BiOI}-2\right)$ 具有最高效的 可见光催化活性.
\end{abstract}

XRD、XPS、SEM和TEM表征表明Bi单质沉积在BiOI表面,整个体系由纳米片自组装为海绵状立体结构. BET比表面 积增大, 结合SEM推测是由纳米片的分层堆叠造成的. UV-DRS表明带隙宽度仅有 $1.8 \mathrm{eV}$ 的BiOI具有可见光响应. EPR和 态密度(DOS)结合可以证明氧缺陷及其激发多个中间能级的存在. 中间能级可以促进电子在可见光下从价带到导带的转 移. PL表明体系中Bi金属的SPR效应所激发的电磁场可以促进光生载流子的分离. 通过DFT理论计算催化剂的电子结构, 差分、电子局域函数(ELF)及电势表明Bi单质和Bi-O层间强的共价作用形成一个通道, 使得热电子从较高电势的Bi单质向 相对低电势的BiOI传递, Bi单质PDOS的计算证明价带变宽归因于Bi元素轨道的贡献, Bi的SPR效应激发BiOI的电子到更高 能级并聚集在价带顶, 这有利于光生载流子的分离. ESR表明提升的电荷分离和迁移率促进了羟基和超氧自由基的产生. 结合表征及理论计算结果, 活性的增强可归因于金属Bi和氧空位的协同效应. 氧缺陷激发的中间能级促进了电荷转移, $\mathrm{Bi}$ 金属的SPR效应使可见光吸收效率提高并且促进了光生载流子分离, 这些是增强光催化性能的关键因素. 此外, 采用原位 红外光谱法(FT-IR)对Bi/BiOI-2的NO吸附和反应过程进行了动态监测. 根据中间产物分析和DFT计算结果, 提出了金属 $\mathrm{Bi}$ 和氧空位协同作用提高 $\mathrm{Bi} / \mathrm{BiOI}$ 光催化性能的机理. 本研究为高性能光催化剂的设计和理解空气净化光催化反应机理提供 了新的思路.

关键词: 表面等离子体共振; 金属Bi; $\mathrm{BiOI}$; 光催化; 氧缺陷; 反应机理

收稿日期: 2018-08-26. 接受日期: 2018-10-17. 出版日期: 2019-06-05.

*通讯联系人. 电话: 15922570175; 电子信箱: dfctbu@126.com

*通讯联系人. 电子信箱: syhsyj@163.com

基金来源：国家自然科学基金(21501016, 21777011, 21822601); 国家重点研发计划(2016YFC02047); 重庆高校创新团队建设计划 (CXTDG201602014); 重庆市自然科学基金(cstc2017jcyjBX0052); 国家“万人计划”青年拔尖人才项目，

本文的电子版全文由Elsevier出版社在ScienceDirect上出版(http://www.sciencedirect.com/science/journal/18722067). 